\title{
Prevalence and risk factors of acute gastroenteritis caused by Rotavirus among children in tertiary hospitals, southeastern Nigeria
}

\author{
${ }^{* 1}$ Igwe, D., ${ }^{2}$ Oshun, P., ${ }^{2}$ Osuagwu, C., ${ }^{1}$ Efunshile, A., and ${ }^{2}$ Oduyebo, 0. \\ ${ }^{1}$ Department of Medical Microbiology, College of Medicine/Alex Ekwueme Federal University Teaching Hospital, \\ Abakaliki, PMB 102, Ebonyi State, Nigeria \\ ${ }^{2}$ College of Medicine/Lagos University Teaching Hospital, Idi-Araba, University of Lagos, Nigeria \\ *Correspondence to: daniel.igwe@npmcn.edu.ng.
}

\begin{abstract}
:
Background: Diarrhea is a worldwide problem and rotavirus is the commonest viral etiologic agent. In Nigeria, diarrhea causes more than 315,000 deaths of preschool-age children annually. In Ebonyi State, it is among the leading causes of pediatric emergency visits and one of the major causes of infant morbidity and mortality. This study was aimed at determining the prevalence and associated risk factors of acute gastroenteritis due to rotavirus infection among under-five children in Abakaliki, Ebonyi state.

Methodology: This was a cross-sectional study of 275 children under 5 years of age hospitalized for acute watery diarrhea, who were consecutively recruited into the study. Stool samples were collected from each child for rotavirus antigen detection using an enzyme-linked immunosorbent assay (ELISA). Socio-demographic information of each child and selected risk factors were collected using structured questionnaire. Data analysis was done on SPSS software version 20.0, and association of demographic characteristics and risk factors with rotavirus diarrhoea was measured using Chi-square test, odds ratio (and 95\% confidence interval). Significant value was set at $p<0.05$.

Results: The prevalence of rotavirus diarrhea among children under 5 years of age in this study was $26.5 \%$ (73/275). Aside from educational level of the mothers, there was no significant association between any of the sociodemographic characteristics and prevalence of rotavirus diarrhoea $(p>0.05)$. Although the prevalence of diarrhoea in the children was lower with the use of maize gruel (pap) as weaning feed $(26.3 \%, 71 / 270)$ compared to the use of other complementary feeding such as 'Cerelac' and 'NAN' $(40 \%, 2 / 5)$, this association did not reach a significant level $(\mathrm{OR}=0.5352,95 \% \mathrm{CI}=0.0875-0.3270, p=0.6110)$, probably due to the small number of children weaned using other complementary feeds.

Conclusion: The relatively high prevalence of rotavirus diarrhea in children under 5 years of age in this study is an indication of the need for the parents/guardians of these children to improve child feeding hygiene.
\end{abstract}

Keywords: Acute gastroenteritis; Rotavirus; ELISA; antigen test; children; Abakaliki; Nigeria

Received Nov 14, 2021; Revised Dec 27, 2021; Accepted Dec 30, 2021; Published online Jan 18, 2022

Copyright 2022 AJCEM Open Access. This article is licensed and distributed under the terms of the Creative Commons Attrition 4.0 International License $<a$ rel="license" href="http://creativecommons.org/licenses/by/4.0/", which permits unrestricted use, distribution and reproduction in any medium, provided credit is given to the original author(s) and the source. Editor-in-Chief: Prof. S. S. Taiwo

\section{Prévalence et facteurs de risque de gastro-entérite aiguë causée par le rotavirus chez les enfants des hôpitaux tertiaires, sud-est du Nigéria}

\author{
${ }^{* 1}$ Igwe, D., ${ }^{2}$ Oshun, P., ${ }^{2}$ Osuagwu, C., ${ }^{1}$ Efunshile, A., et ${ }^{2}$ Oduyebo, 0.
}

${ }^{1}$ Département de Microbiologie Médicale, Collège de Médecine/Hôpital Universitaire Fédéral Alex Ekwueme, Abakaliki, PMB 102, État d'Ebonyi, Nigéria

${ }^{2}$ Collège de Médecine/Hôpital Universitaire de Lagos, Idi-Araba, Université de Lagos, Nigéria

*Correspondance à: daniel.igwe@npmcn.edu.ng 


\section{Résumé:}

Contexte: La diarrhée est un problème mondial et le rotavirus est l'agent étiologique viral le plus courant. Au Nigeria, la diarrhée provoque chaque année plus de 315000 décès d'enfants d'âge préscolaire. Dans l'État d'Ebonyi, c'est l'une des principales causes de visites aux urgences pédiatriques et l'une des principales causes de morbidité et de mortalité infantiles. Cette étude visait à déterminer la prévalence et les facteurs de risque associés de gastro-entérite aiguë due à une infection à rotavirus chez les enfants de moins de cinq ans à Abakaliki, dans l'État d'Ebonyi. Méthodologie: Il s'agissait d'une étude transversale portant sur 275 enfants de moins de 5 ans hospitalisés pour diarrhée aqueuse aiguë, qui ont été recrutés consécutivement dans l'étude. Des échantillons de selles ont été prélevés sur chaque enfant pour la détection de l'antigène du rotavirus à l'aide d'un dosage immuno-enzymatique (ELISA). Les informations sociodémographiques de chaque enfant et les facteurs de risque sélectionnés ont été collectés à l'aide d'un questionnaire structuré. L'analyse des données a été effectuée sur le logiciel SPSS version 20.0, et l'association des caractéristiques démographiques et des facteurs de risque avec la diarrhée à rotavirus a été mesurée à l'aide du test du chi carré, du rapport de cotes (et de l'intervalle de confiance à 95\%). La valeur significative a été fixée à $p<0,05$.

Résultats: La prévalence de la diarrhée à rotavirus chez les enfants de moins de 5 ans dans cette étude était de $26,5 \%(73 / 275)$. Mis à part le niveau d'éducation des mères, il n'y avait pas d'association significative entre les caractéristiques sociodémographiques et la prévalence de la diarrhée à rotavirus $(p>0,05)$. Bien que la prévalence de la diarrhée chez les enfants ait été plus faible avec l'utilisation de gruau de maïs (pap) comme aliment de sevrage $(26,3 \%, 71 / 270)$ par rapport à l'utilisation d'autres aliments complémentaires tels que «Cerelac» et «NAN» (40\%, $2 / 5)$, cette association n'a pas atteint un niveau significatif $(\mathrm{OR}=0,5352$, IC 95\% $=0,0875-0,3270, p=0,6110)$, probablement en raison du faible nombre d'enfants sevrés utilisant d'autres aliments complémentaires. Conclusion: La prévalence relativement élevée de la diarrhée à rotavirus chez les enfants de moins de 5 ans dans cette étude est une indication de la nécessité pour les parents/tuteurs de ces enfants d'améliorer l'hygiène alimentaire des enfants.

Mots-clés: Gastro-entérite aiguë; Rotavirus; ELISA; test d'antigène; enfants; Abakaliki; Nigeria

\section{Introduction:}

Diarrhea is a worldwide problem, and despite the global public health intervention in water supply, diarrhea remains the second leading cause of death, after pneumonia, in children under 5 years of age (1). Globally, an estimate of more than 110 million diarrheal cases and 2 million hospitalizations, resulting in more than $17 \%$ of childhood deaths, are reported annually (2). In developing countries, most of the diarr-hea cases are usually severe enough to require hospitalization, with 1.87 million deaths in children before the age of 5 years (2). Again, in surviving children, severe diarrhea presents with some complications such as malabsorption syndrome, malnutrition (conditions often associated with poor cognitive function), failure to thrive in early childhood, and increased susceptibility to other infections (3).

In children, rotavirus is the commonest viral etiologic agent of diarrhea globally, and rotavirus group $A$ is the most frequent (4). Also, a previous study confirmed that rotavirus accounted for $37.1 \%$ of acute diarrheal hospitalizations (5). The virus is detected more in diarrhea stools $(87 \%)$ than in normal stools $(30.6 \%)$ and younger children are more vulnerable than the older ones with the peak incidence between 6 and 24 months (6).

In Nigeria, reports have shown that rotavirus is a very common etiologic agent of diarrhea in children under 5 years of age and causes more than 315,000 deaths of preschool- age children annually (5,7-14). In Ebonyi State of Nigeria, diarrhea is among the leading causes of paediatric emergency visits and one of the major causes of infant morbidity and mortality (15). The aim of this study, therefore, was to determine the prevalence of and risk factors for rotavirus diarrhea among hospitalized children under 5 years of age in two tertiary hospitals in southeastern Nigeria.

\section{Materials and method:}

\section{Study setting}

The study was conducted in Abakaliki, the capital city of Ebonyi State, Nigeria. The State borders with Enugu State in the west, Cross River State in the east, Benue State in the north, and Abia State in the south. There are two distinct seasons; wet and dry seasons occurring between April to October and November to March respectively. The State has poor access to adequate potable water, poor sanitation, and hygiene, with a consequent increase in diarrhea cases, especially in children. It has a population of about two million people out of which $42.7 \%$ are children, with $11.7 \%$ below 4 years of age (16).

The study area is traversed by several rivers which constitute sources of water supply especially to the suburbs and rural communities. This may serve for drinking, washing and bathing, and irrigation purposes for medium and small-scale farming which is a major occupation of the people. 


\section{Study design}

This was a descriptive cross-sectional study of children below 5 years of age conducted in the two major hospitals; Alex Ekwueme Federal University Teaching Hospital, Abakaliki (AEFUTHA), and Mile 4 Hospital, Abakaliki, Ebonyi State, from Jan to April 2019.

\section{Sample size and study eligibility}

Sample size for the study was calculated using the formula; $N=z^{2} p q / d^{2}(17)$, where $N$ is the desired sample size, ' $z$ ' is the standard normal deviation usually set at 1.96 corresponding to $95 \%$ confidence interval, ' $p$ ' is the prevalence of rotavirus which was $19.2 \%$ from a previous study (10), ' $q$ ' is $1-p$, and ' $d$ ' is the standard error (margin of error) set at 0.05 . This gave a sample size of 238 that was increased after considering $15 \%$ attrition to 275 participants.

Eligibility criteria for the study were children below 5 years of age who presented with acute watery stools (passage of 3 or more loose stools per day) with or without blood or fever at the participating health facilities, and informed consents of each parent or guardian. Children with chronic or persistent diarrhea (diarrhea that has lasted for more than 14 days) were excluded.

\section{Ethical approval}

Ethical approval was obtained from the Research and Ethics Committee of the two hospitals. Written informed consent, explained in the local language where necessary, was also obtained from each parent/guardian.

\section{Sampling technique and data collection}

Eligible children at each of the healthcare facility was consecutively recruited into the study until the sample size was attained (this was over a period of 4 months). A structured questionnaire was used to collect socio-demographic information and some selected risk factors such as age, gender, weight, place of residence, educational level of parent/caregivers, occupation of fathers, rotavirus immunization and feeding history.

\section{Sample collection and laboratory analysis Stool samples from eligible participants were collected into a clean plastic bottle and transported in a Giostyle cool box containing some icepacks to Virology Laboratory in the Alex Ekwueme Federal University Teaching Hospital where they were stored in a deep freezer at - $70^{\circ} \mathrm{C}$. The samples were then transported in a triple layer-packaging with icepacks to the Central Research Laboratory, College of Medi- cine, University of Lagos, for analysis.}

The AccuDiag ${ }^{T M}$ Rotavirus (Fecal) ELISA kits (Diagnostic Automation Incorporation, DAI, USA) were used to detect rotavirus antigens present in the stool samples, according to the standard operating procedure of the manufacturer's instruction.

First, all reagents were brought to room temperature $\left(15-30^{\circ} \mathrm{C}\right)$ and all frozen samples were thawed completely before use. Ninety-six test wells were placed in a strip holder. One hundred micro liter $(100 \mu \mathrm{l})$ each of the negative control, positive control, and stool supernatant were pipetted to the appropriate test wells. This was incubated at room temperature for 30 minutes, then washed three times. After the last wash, the wells were slapped out on a clean absorbent towel to remove excess wash buffer. Two drops of Reagent 1 (blue solution) were added to each well, incubated at room temperature for 5 minutes, and then washed. After the last wash, the wells were slapped out on a clean absorbent towel to remove excess wash buffer. Two drops of Reagent 2 (red solution) were added to each well, incubated at room temperature for 5 minutes, then washed 3 times. After the last wash, wells were slapped out on a clean absorbent towel to remove excess wash buffer. Two drops of Chromogen were then added to each well followed by incubation at room temperature for 5 minutes. Finally, 2 drops of Stop Solution were added to each well and mixed thoroughly by gently tapping the side of the strip holder with the index finger.

Washings at each stage were done by vigorously filling each well to overflowing and decanting contents 3 separate times. Results were read using the ELISA plate reader. All the wells were read using bichromatic reading with fiber at $450 \mathrm{~nm}$ and $620-650 \mathrm{~nm}$. The cut-off mark was at 0.15 optic density (OD) with an absorbance reading of 0.15 OD and above taken to be positive while reading less than 0.15 OD was taken to be negative.

\section{Statistical analysis of data}

All data were analyzed using SPSS statistical software for Windows $\AA$ version 20, 2012 (IBM Inc., Chicago Illinois, USA). Categorical and discrete variables were summarized using frequency and percentage. Association of variables with prevalence of rotavirus diarrhoea was measured using Chi-square test, odd ratio (and $95 \%$ confidence interval). Significant value was set at $p<0.05$.

\section{Results:}

Sociodemographic characteristics of children As shown in Table 1, of the total of 275 children recruited into this study, 168 (61.1\%) 
were males while 107 (38.9\%) were females. Most of the children $(n=152,55.1 \%)$ were within the ages of $1-11$ months while 123 $(44.7 \%)$ were between the ages of 12 and 59 months, $120(43.6 \%)$ lived in rural areas while $155(56.4 \%)$ lived in urban settings.

Of the 275 children, 73 tested positive for rotavirus antigen, giving a prevalence of $26.5 \%$. The prevalence of rotavirus diarrhea in male children was $25 \%$ (42/168), which was not significantly different from the prevalence of $29 \%(31 / 107)$ in female children $(O R=0.8172$, $95 \%$ CI $0.4741-1.409, p=0.481)$. The rotavirus prevalence of $25.7 \%$ (39/152) in children between 1-11 months of age was also not significantly different from the rotavirus prevalence of $27.6 \%(34 / 123)$ in children $12-59$ months of age $(\mathrm{OR}=0.9034,95 \% \mathrm{CI}=0.5279-1.546, p=$ 0.7838 ). However, the prevalence of rotavirus was significantly higher in children whose mothers had secondary level of education $(33.8 \%, 49 / 145)$ than those whose mothers had higher level (University and Polytechnic) of education (17.3\%, 13/75) and those whose mothers had no education or only primary school leaving certificate level of education
$(20.0 \%, 11 / 55)\left(X^{2}=13.680, p=0.0084\right)$. There was no significant difference $(p>0.05)$ in the prevalence of rotavirus diarrhoea among the children in relation to other sociodemographic factors such as family type, care giver, and occupation of the fathers (Table 1 ).

\section{Risk factors for rotavirus diarrhea}

Table 2 depicts the investigated risk factors in relation to the prevalence of rotavirus diarrhea, which showed that none of the factors was significantly associated with prevalence of rotavirus diarrhoea $(p>0.05)$. Although the prevalence of diarrhoea in the children was lower with the use of maize gruel (pap) as weaning feed $(26.3 \%, 71 / 270)$ compared to the use of other complementary feeding such as 'Cerelac' and 'NAN', $(40 \%, 2 / 5)$, this association did not reach a significant level $(\mathrm{OR}=0.5352,95 \% \mathrm{CI}=$ 0.0875-0.3270, $p=0.6110$ ).

The prevalence of rotavirus diarrhea was higher in those who were not exclusively breastfed $(29.2 \%, 28 / 96)$ than in those who were exclusively breast fed $(25.1 \%, 45 / 179)$ but this also did not reach a significant level (OR= $0.8156,95 \% \mathrm{CI}=0.4683-1.420, p=0.4772)$.

Table 1: Prevalence of rotavirus diarrhoea in relation to socio-demographic characteristics of children in tertiary hospitals, southeastern Nigeria

\begin{tabular}{|c|c|c|c|c|c|}
\hline \multirow[t]{2}{*}{ Socio-demographic variables } & \multicolumn{3}{|c|}{ Rotavirus status by ELISA antigen results } & \multirow{2}{*}{$\begin{array}{c}\text { OR } \\
(95 \% \mathrm{CI})\end{array}$} & \multirow[t]{2}{*}{$p$ value } \\
\hline & $\begin{array}{c}\text { No positive (\%) } \\
n=73(26.5)\end{array}$ & $\begin{array}{c}\text { No negative (\%) } \\
n=202(73.5)\end{array}$ & $\begin{array}{c}\text { Total } \\
n=275\end{array}$ & & \\
\hline \multicolumn{6}{|l|}{ Age group (in months) } \\
\hline $1-11$ & $39(25.7)$ & $113(74.3)$ & 152 & 0.9034 & 0.7838 \\
\hline $12-59$ & $34(27.6)$ & $89(72.4)$ & 123 & $(0.5279-1.546)$ & \\
\hline \multicolumn{6}{|l|}{ Gender } \\
\hline Male & $42(25.0)$ & $126(75.0)$ & 168 & 0.8172 & 0.4861 \\
\hline Female & $31(29.0)$ & $76(71.0)$ & 107 & $(0.4741-1.409)$ & \\
\hline \multicolumn{6}{|l|}{ Care giver } \\
\hline Mother & $70(27.2)$ & $187(72.8)$ & 257 & 1.872 & 0.4167 \\
\hline Nanny & $3(16.7)$ & $5(83.3)$ & 23 & $(0.5256-6.664)$ & \\
\hline \multicolumn{6}{|l|}{ Family type } \\
\hline Monogamous & $67(26.6)$ & $185(73.4)$ & 252 & 1.026 & 1.0000 \\
\hline Polygamous & $6(26.1)$ & $17(73.9)$ & 23 & $(0.3883-2.712)$ & \\
\hline \multicolumn{6}{|l|}{ Educational level of mother } \\
\hline University/Polytechnic & $13(17.3)$ & $62(82.7)$ & 75 & $13.680^{+}$ & $0.0084 *$ \\
\hline Secondary school & $49(33.8)$ & $96(66.2)$ & 145 & & \\
\hline FSLC/No education & $11(20.0)$ & $44(80.0)$ & 55 & & \\
\hline \multicolumn{6}{|l|}{ Occupation of father } \\
\hline Professional/civil servant & $20(24.4)$ & $62(75.6)$ & 82 & $3.174^{+}$ & 0.5292 \\
\hline Politician & $3(23.1)$ & $10(76.9)$ & 13 & & \\
\hline Businessman & $38(25.3)$ & $112(74.7)$ & 150 & & \\
\hline Skilled artisan & $6(40.0)$ & $9(60.0)$ & 15 & & \\
\hline Unskilled worker & $6(40.0)$ & $9(60.0)$ & 15 & & \\
\hline
\end{tabular}


Table 2: Prevalence of rotavirus diarrhea in relation to selected risk factors among children in tertiary hospitals, southeastern Nigeria

\begin{tabular}{|c|c|c|c|c|c|}
\hline \multirow[t]{2}{*}{ Risk factors } & \multicolumn{3}{|c|}{ Rotavirus status by ELISA test results } & \multirow{2}{*}{$\begin{array}{c}\text { OR } \\
(95 \% \mathrm{CI})\end{array}$} & \multirow[t]{2}{*}{$p$ value } \\
\hline & $\begin{array}{c}\text { No positive (\%) } \\
n=73(26.5)\end{array}$ & $\begin{array}{c}\text { No negative (\%) } \\
n=202(73.5)\end{array}$ & $\begin{array}{c}\begin{array}{c}\text { Total } \\
\mathbf{n}=\mathbf{2 7 5}\end{array} \\
\end{array}$ & & \\
\hline \multicolumn{6}{|l|}{ Exclusive breastfeeding } \\
\hline Yes & $45(25.1)$ & $134(74.9)$ & 179 & 0.8156 & 0.4772 \\
\hline No & $28(29.2)$ & $68(70.8)$ & 96 & $(0.4683-1.420)$ & \\
\hline \multicolumn{6}{|l|}{ Complementary feeding } \\
\hline Maize gruel & $71(26.3)$ & $199(73.7)$ & 270 & 0.5352 & 0.6110 \\
\hline Others & $2(40.0)$ & $3(60.0)$ & 5 & $(0.0875-0.3270)$ & \\
\hline \multicolumn{6}{|l|}{ Preparation of baby's food by; } \\
\hline Mother & $73(27.0)$ & $197(73.0)$ & 270 & 4.094 & 0.3295 \\
\hline Nanny & 0 & $5(100)$ & 5 & $(0.2234-75.007)$ & \\
\hline \multicolumn{6}{|l|}{ Source of drinking water } \\
\hline Processed water (bottle/sachet) & $38(23.6)$ & $123(76.4)$ & 161 & $3.095^{+}$ & 0.3772 \\
\hline Rain & $2(18.2)$ & $9(81.8)$ & 11 & & \\
\hline Borehole/Well & $28(33.3)$ & $56(66.7)$ & 84 & & \\
\hline Stream & $5(26.3)$ & $14(73.7)$ & 19 & & \\
\hline \multicolumn{6}{|l|}{ Method of fecal waste disposal } \\
\hline Water closet & $43(24.7)$ & $131(75.3)$ & 174 & $3.397^{+}$ & 0.3344 \\
\hline Pit latrine & $11(28.2)$ & $28(71.8)$ & 39 & & \\
\hline Bush & $18(29.5)$ & $43(70.5)$ & 61 & & \\
\hline Stream & $1(100.0)$ & 0 & 1 & & \\
\hline
\end{tabular}

\section{Discussion:}

This study showed the burden of rotavirus diarrhea among under 5 years of age in Abakaliki, with a high prevalence of rotavirus diarrhea of $26.5 \%$ being reported. This is comparable to similar studies in Abuja with a prevalence of $25 \%$ (18), Lagos with $25.8 \%$ (19) and Sokoto with $25.5 \%(20)$. However, the rate in our study is lower than the prevalence of $31.5 \%$ in Enugu (13), 37.1\% in Asaba (5), $38.1 \%$ in Maiduguri (12), and $32.2 \%$ in Kaduna (21). The observed similarities and differences in prevalence with these studies and our study may be attributed to differences in methodology, study design, time and season of sample collection, sample storage, geographical location, or changes in environmental or socio-economic factors. Again, it might as well reflect changing trends of rotavirus infection (22).

Our study revealed that there was no statistically significant difference in the prevalence of rotavirus infection in relation to age groups (1-11 months and 12-59 months) and gender. This finding is consistent with a previous study in Jos (7). Although the detection rate of rotavirus antigen was slightly higher in female $(29 \%, 42 / 168)$ than in male children $(25 \%$, $31 / 107)$, this difference was not significantly different $(p=0.4861)$. Similar observations were made in studies from Abuja, Jos and Katsina $(7,18,23)$. However, it is in contrast with the studies from Benin and Asaba where significantly higher percentages in females than males were reported $(5,10)$. The only socio-demographic factor significantly associated with prevalence of rotavirus diarrhoea in our study was educational level of the mothers, which showed that the prevalence was higher in mothers with secondary level of education than those with higher education (University and Polytechnic), and those with no education or school leaving certificate education level $(p=0.0086)$.

None of the selected risk factors such as the history of exclusive breastfeeding, preparation of children meal, sources of drinking water, and methods of fecal disposal was significantly associated with prevalence of rotavirus diarrhoea. Although the use of maize gruel (pap) as weaning meal was associated with a lower prevalence of rotavirus diarrhoea $(26.3 \%)$ compared to use of other complementary feeding such as 'Cerelac' and 'NAN' (40.0\%), this association did not reach statistically significant level $(p=0.6110)$, probably due to the small number of children weaned with complementary feeds $(n=5)$. Nevertheless, the higher prevalence of rotavirus diarrhea in these children may be explained by the fact that preparation of maize gruel (pap) requires the use of boiling water $\left(100^{\circ} \mathrm{C}\right)$ as opposed to complementary feeds that do not require such procedure in their preparation. Rotaviruses are not likely to survive the high temperature of boiling.

Our study findings agree largely with a similar study in Asaba (5) where apart from younger age group, no other risk factors including complementary feeding type, was asso- 
ciated with prevalence of rotavirus diarrhoea. Again, the findings in our study of exclusive breastfeeding and sources of drinking water not significantly associated with prevalence of rotavirus diarrhea were similar to those reported in the study conducted in Benin (10).

\section{Conclusion:}

The relatively high prevalence of rotavirus diarrhea in children under 5 years of age in Abakaliki, reported in our study is an indication of the need for the parents/guardians of these children to improve child feeding hygiene.

\section{Acknowledgments:}

The authors are grateful to the participants and their parents/guardians who accepted to be enrolled in this study. Our colleagues who assisted in one way or the other towards the completion of this research project are thankfully acknowledged.

\section{References:}

1. WHO/United Nation Inter-Agency Group for Child Mortality Estimation (UN IGME). Levels and trends in child mortality. Report 2017. https://www.unicef.org/media/47626/file/UNIGME-Child-Mortality-Report-2018. (Accessed Nov 8, 2018)

2. Mathers, C. D., Boerma, T., and Fat, D. M. Global and regional causes of death. Br Med Bull. 2009; 92 (1): 7-32

3. Ijaz, M. K., and Rubino, J. R. Impact of infectious diseases on cognitive development in childhood and beyond: Potential mitigation role of hygiene. The Open Infect Dis J. 2012; 6: 65-70.

4. Lundgren, O., and Svensson, L. Pathogenesis of rotavirus diarrhea. Microbes Infect. 2001; 3: $1145-1156$

5. Uzoma, E. B., Chukwubuikem, C., Omoyibo, E., and Tagbo, O. Rotavirus genotypes and the clinical severity of Diarrhoea among children under 5 years of age. Nig Postgrad Med $\mathrm{J}$. 2016; 23: 1-5.

6. Clark, H. F., Marcello, A. E., and Lawley, D. Unexpectedly high burden of rotavirus gastroenteritis in very young infants. BMC Pediatr. 2010; 10: 40.

7. Junaid, S. A., Umeh, C., Olabode, A. O., and Banda, J. M. Incidence of rotavirus infection in children with gastroenteritis attending Jos university teaching hospital, Nig Virol J. 2011; 8: 233.

8. Odimayo, M. S., Olanrewaju, W. I., Omilabu, S. A., and Adegboro, B. Prevalence of rotavirus-induced diarrhea among children under 5 years in Ilorin, Nigeria. J Trop Pediatr. 2008; 54: 343-346.

9. Aminu, M., Esona, M. D., Geyer, A., and Steele
A. D. Epidemiology of rotavirus and astrovirus infections in children in northwestern Nigeria. Ann Afr Med. 2008; 7: 168-174

10. Iyoha, O., and Abiodun, P. O. Human rotavirus genotypes causing acute watery diarrhea among under-five children in Benin City, Nigeria. Niger J Clin Pract. 2015; 18: 48-51.

11. Faleye, T. O. C., George, U. E., Simsek, C., et al. Reference human rotavirus $A$ genome sequence from a previously vaccinated child with diarrhea in Nigeria. Microbiol Resour Announc. 2020; 9: e01352-19

https://doi.org/10.1128/MRA.01352-19.

12. Akinola, M. T., Uba, A., Umar, A. F., and Agbo, E. B. Diversity of rotavirus strains circulating in Maiduguri, Borno State, Northeast, Nigeria. African Journal Online (AJOL); 2019, 76 (4-6):

13. Ojobor, C. D., Olovo, C. V., Onah, L. O., and Ike, A. C. Prevalence and associated factors to rotavirus infection in children less than 5 years in Enugu State, Nigeria. Virus Dis. 2020; 31 (3): 316-332

https://doi.org/10.1007/s13337-020-00614-x

14. Babaniyi, O. A. Oral Dehydration of Children with Diarrhea in Nigeria, A 12 Year Renew of Impact on Morbidity and Mortality from Diarrhea Disease and Diarrhea Treatment Practices. J Trop Paediatr. 1991; 37: 16-66.

15. Anyanwu, O. U., Ezeanosike, O. B., and Ezeonu, C. T. Pattern and outcome of admissions at the children's emergency room at the Federal Teaching Hospital Abakaliki. Afr J Med HIth Sci. 2014; 13: 6-10.

16. National Population Commission/National Bureau of Statistics. Annual Abstract of Statistics; 2011; 1: 18. https://istmat.info/ files/uploads/53129/annual_abstract_of_stati stics_2011

17. Araoye M. O. Research Methodology with Statistics for Health and Social Sciences. Nathadex publishers Ilorin, 2004:25- 120

18. Udeani, T. K., Ohiri, U. C., Onwukwe, O. S., and Chinedu, C. Prevalence and Genotypes of Rotavirus Infection among Children with Gastroenteritis in Abuja, Nigeria. Res J Microbiol. 2018; 13: 84-92.

19. Ayolabi, C. I., Ojo, D. A., and Armah, G. E. Electropherotypes and G-types of Group A rotaviruses detected in children with diarrhea in Lagos, Nigeria. ISRN Virology. 2013; 2013: 79-84.

20. Alkali, B. R., Daneji, A. I., Magaji, A. A., and Bilbis, L. S. Clinical symptoms of human rotavirus infection observed in children in Sokoto, Nigeria. Adv Virol. 2015; 2015: 890895.

21. Mohammed, A., Aminu, M., Ado, S., Jatau, E., and Esona, M. Prevalence of rotavirus among children under five years of age with diarrhea in Kaduna State, Nigeria. Nig J Paediatr. 2016; 43 (4): 264-268.

22. Center for Disease Control (CDC). Rotavirus Surveillance Worldwide, 2001-2008.

https://www.cdc.gov/mmwr/preview/mmwrht $\mathrm{ml} / \mathrm{mm} 5746 a 3 . h t m$ (Accessed 25 $5^{\text {th }}$ Jan 2020).

23. Mukhtar. G. L., Aminu, M., Yakubu, S. E., and Esona, M. D. Prevalence and Clinical Manifestations of Rotavirus and Adenovirus Infections in Children Under Five Years Old in Katsina State, Northwestern Nigeria. Int J Adv Res. 2016; 4 (7): 528-536. 